\title{
La historia en el cine: la dicotomía orden/transgresión en la película Hidalgo. La historia jamás contada, de Antonio Serrano.
}

\author{
History and movies: the dichotomy order/transgression in the film \\ Hidalgo. La historia jamás contada, by Antonio Serrano.
}

Esta obra está bajo una Licencia Creative Commons Atribución 4.0 Internacional. DOI: $10.32870 /$ sincronia.axxiii.n75.18a19

Jorge Alberto Ruiz Barriga

Universidad Michoacana de San Nicolás de Hidalgo

joruba79@hotmail.com

(MÉXICO)

Juan Carlos González Vidal

Universidad Michoacana de San Nicolás de Hidalgo

juanvit@hotmail.com

(MÉXICO)

Recibido: 04/10/2018

Revisado: 01/11/2018

Aprobado: 03/12/2018

\section{RESUMEN}

El cine se presenta como una oportunidad para analizar la interpretación de la historia a través de un campo ficcional. De ahí la importancia de revisar la confluencia entre historia y cine. En este caso nos interesa analizar la deconstrucción que se manifiesta en la visión de la historia nacional que mitifica a personajes históricos como sucede en el filme Hidalgo la historia jamás contada, texto en el que ubicamos una dicotomía de orden/transgresión que guía al relato ficcional e histórico. Desde la historia y la semiótica observaremos la modelizaciones que sufre el personaje histórico de Miguel 
Hidalgo héroe de la Independencia de México. Asimismo, nos anclaremos en los polos de cultura e identidad para caracterizar la construcción de estos relatos.

Palabras clave: Historia. Cine. Semiótica. Identidad. Cultura. Miguel Hidalgo.

\begin{abstract}
Movies could be a good opportunity if we are insterested in analyzing the convergence between History and fiction. In this article, we want to review the deconstruction which is manifested in the vision of national history that mythifies historical figures as in the film Hidalgo, la historia jamás contada, text in which we locate the next dichotomy: order/transgression. This structure guides both, the fictional story and historical discourse. Using tols from History and semiotics, we will analyze the way that the historical caracter, Miguel Hidalgo, is configured. On the other hand, we will travel through two poles: culture and identity, to characterize the construction of the above fictional story and historical discourse.
\end{abstract}

Keywords: History. Movies. Semiótics. Identity. Culture. Miguel Hidalgo.

\title{
1.- Introducción
}

Este trabajo se ocupa de la confluencia entre la historia y cine en el texto fílmico Hidalgo. La historia jamás contada, del cineasta mexicano Antonio Serrano, y tiene como hilo conductor la dicotomía orden/transgresión, que nos llevará a identificar los aspectos medulares de una humanización/desmitificación en este texto.Tomaremos la historia como un pre-texto que organiza unidades de sentido de acuerdo a reglas codiciales específicas. Uno de estos procedimientos que utiliza la historia proviene de códigos referenciales, que la convierte en un objeto de estudio apto para una perspectiva significativo-comunicativa. Desde la semiótica podemos preguntarnos, si la "ciencia histórica" colocada bajo la búsqueda imperiosa de lo real y racional, difiere de las narraciones imaginarias, la respuesta es compleja, pero podemos estar de acuerdo en que "la condición de un escrito histórico parece estar definida por una combinación de significaciones 
únicamente articuladas y presentadas en términos de hechos" (De Certeau. 1993, p. 57, 101, 102, y 104). El relato histórico se refiere a coordenadas espacio-temporales consideradas como verídicas, de ahí surge el efecto de verdad que lo caracteriza.

La construcción de la escritura histórica nos remite a una organización de significantes que siguen un orden cronológico y tiene una estructura de conclusión. Con esta disposición cronológica, la historiografía nos plantea un tiempo para las cosas como eje y la condición de un tiempo discursivo, que es distante del tiempo real (De Certeau, 1993, p. 101, 102 y 104).

Tomar como punto de partida los vínculos de la "realidad" con la "ficción" para abarcar la convergencia de la producción semiósica entre la historia y el cine, es uno de los principales objetivos de esta investigación. En esta relación, observamos a los hechos históricos como significantes y nos percatamos de que la construcción del relato histórico puede llegar a ser permeado por la ficción cuando el historiador construye la trama de su relato de acuerdo a una selección de hechos.

Nuestros planteamientos se acomodan con la denominada new cultural history que se puso de moda en el léxico de los historiadores a partir de 1989, cuando un conjunto de ensayos coordinados por Lynn Hunt tuvieron como objetivo presentar trabajos sobre textos, imágenes, rituales etc. proponiendo una manera inédita de abordar las relaciones entre las formas simbólicas y el mundo social. En esta new cultural history se comenzaron a utilizar modelos de interpretación de disciplinas vecinas como la antropología, la crítica literaria y la semiótica (Chartier, 2005, p. 13 y 14.).

Esta propuesta se conduce más por estudios de caso que mediante teorización global, invitando a los historiadores a reflexionar sobre la manera de construir las narraciones y los análisis históricos. Para ello, los conceptos y modelos fueron tomados de antropólogos como Víctor Turner y Clifford Geertz; con la participación de la historia de las mentalidades impulsada por los Annales y de las ideas promovidas por la "microhistoria" italiana referentes a la reducción de la escala de observación, o como también lo llama Ginzburg, el "paradigma indiciario". Este último es un privilegio que facilita a un individuo comprender o interpretar en función de su propia cultura, ideas y creencias, los textos y las imágenes que circulan en una sociedad (Chartier, 2005, p. 14, 19 y 20). 
La importancia de los relatos visuales que se encargan de mostrarnos hechos históricos, nos remiten a tomar en cuenta el cine, como un relato cargado de un "efecto de realidad" o una "ilusión de realidad". Es de todos sabido el potencial del cine como fuente histórica, sin embargo en esta investigación, más allá de utilizar la imagen como documento, nos interesa (como dijimos) la confluencia de campos simbólicos entre la historia y el cine (Chartier, 2005, p. 195).

Para la película de Hidalgo. La historia jamás contada, tenemos por un lado un relato de orden factual (el histórico) y por el otro, uno de orden ficcional (el cinematográfico), produciéndose una convergencia entre estos dos campos o zonas especializadas de conocimiento, que están cargados de relaciones actanciales, actoriales y configuraciones semánticas ya dadas. Sin embargo, estos elementos son susceptibles de sufrir transformaciones, ya que los cambios de contexto y de circunstancia conllevan modificaciones forzosas, cuando menos a nivel de contenido. Ahora bien, el cambio de contexto se refiere principalmente al cambio de un campo simbólico a otro, involucrando con ello, diferentes reglas de producción textual (semiosis) (González Vidal, 2008, p. 34)

Esta película narra ciertos pasajes de la vida de Miguel Hidalgo y Costilla, el héroe que encabezó la Independencia de México frente a la dominación de España. El personaje es representado en tres etapas de su vida: su adolescencia, su período como clérigo y en la víspera de su ejecución, pero desprendido de su acartonado altar como héroe de la patria para situarlo en un hábitat terrenal, entre dilemas e ilusiones humanas. Así, la película acude a algunas referencias historiográficas de la vida del personaje, aunque hay una fuerte dosis de ficción en el relato.

De acuerdo con Antonio Serrano, la cinta está alejada de la historia oficial y narra principalmente la parte juguetona, blasfema e irreverente del "Padre de la Patria", con ello busca eximir la solemnidad patriotera con la que se ha forjado la imagen de los héroes de la Independencia de México. El director de esta película no tuvo la intención de explicar la historia de manera convencional apegada al libro escolar, al contrario, su fin era presentar un Hidalgo "fresco" y "actual". Utiliza la libertad narrativa y desdeña la historiografía convencional (Lara Chávez, 2010). 
Hidalgo. La historia jamás contada, buscaba presentar a un Miguel Hidalgo más real y no como una estatua glorificada; su pretensión era contar la historia del cura, del hombre, del héroe, pero también del personaje que amaba el juego, a las mujeres y también el teatro (esto según Serrano). Esta cinta formó parte de los proyectos cinematográficos para conmemorar el Bicentenario de la Independencia y el Centenario de la Revolución y fue distribuida por 20th Century Fox con 450 copias.

Además de Serrano, intervienen en la cinta: Guion: Leo Eduardo Mendoza y Antonio Serrano. Fotografía: Emiliano Villanueva. Dirección de arte: Brigitte Broch. Vestuario: Leticia Palacios. Producción: Astillero Films. Coproducción: Wanda Films. Productores: Lourdes García y Luis Urquiza. Productores asociados: Inna Payán y Carlos Payán. Actores: Demián Bichir (cura Miguel Hidalgo), Ana de la Reguera (Josefa Quintana), Miguel Rodarte (José Santos), Gerardo Trejo Luna (clérigo Ramírez), Juan Ignacio Aranda (José Quintana), Cecilia Suárez (Amadita), Andrés Palacios (Morelos). (Molina Ramírez, 2010).

El texto, como lo mencionamos, aborda tres momentos de la vida de Miguel Hidalgo y Costilla. 1) Castigo y ejecución, 2) Juventud y 3) Madurez y libertad, y su estructura se aparta del orden cronológico característico del relato histórico, libertad permitida por el cine.

\section{2.-El texto y sus etapas}

a) Castigo y ejecución.

Este episodio consta de cuatro intervenciones de manera continua en tiempo presente. La narración comienza en Chihuahua, en el lapso de su captura encerrado en su celda, con un Hidalgo maduro, castigado, torturado y, hasta cierto punto, resignado. Afuera de la prisión los criollos agraviados por las acciones del cura insurgente, gritan con odio, "iasesino!", mientras sus inquisidores lo maldicen en nombre de la Iglesia, inmediatamente se le otorga el carácter de infractor, cuando se le acusa de ser el incitador de los robos, rapiñas, sacrilegios, herejías y afrentas contra Dios, expulsándolo de la 
Iglesia y entregándolo a la justicia de los hombres. Desde este punto histórico, el personaje realiza diversas analepsis cronológicamente ordenadas.

Dentro de su celda, Hidalgo padece las pesadillas de los recuerdos de la guerra; la imagen de la matanza de españoles en Guanajuato deja entrever un sentimiento de culpabilidad y justificación de los hechos. El oficial realista Ángel Abella a través de un interrogatorio lo acusa de asesino, mientras Hidalgo justifica su lucha por la Independencia. Se le cuestiona su vida en amancebamiento siendo párroco, dando como respuesta que es "Dios quien debe juzgar a cada quien por sus actos". El episodio concluye con su ejecución.

b) Juventud.

Esta etapa nos remite a su época de estudiante en el Colegio Jesuita de Pátzcuaro en 1767. Ahí aparece un Hidalgo joven y curioso que tiene el gusto por la lectura de libros prohibidos por la Inquisición española, los cuales obtiene a través de su relación con un indio nigromante, cuyas acciones y modo de vida están en contra del orden establecido. El teatro se convierte en un medio de crítica contra el fanatismo, promoviendo en el joven Hidalgo la utilización de la razón sobre la fe.

Hidalgo corre por los pasillos del colegio jesuita huyendo para que no descubran el libro prohibido que esconde entre sus ropas, y aparece abruptamente en el escenario de la obra de teatro montada por el padre Urquiza, quien lo salva de ser descubierto. En la cocina del colegio le confiesa a un compañero que él no sentía la vocación para ser religioso y simplemente seguía los deseos de su padre. Antes de representar la obra de teatro que habían ensayado, son interrumpidos por el ejército real que llevaba las instrucciones de expulsar a la orden de los jesuitas de la Nueva España; este hecho marcó los sentimientos de Hidalgo hacia los gobiernos tiranos.

c) Madurez y libertad.

Este período transcurre después de 1787, el más amplio del texto. Se centra en el momento en el cual Hidalgo impartía cátedra y era regente del Colegio de San Nicolás Obispo en Valladolid. En un 
aula de clases se le observa debatiendo con sus alumnos sobre la "tiranía" y la "libertad", en esa discusión participa Morelos reafirmando lo dicho por su maestro. El debate termina en un desacuerdo sobre la igualdad que debería existir entre los pobladores de la Nueva España.

La trama nos presenta a un Hidalgo maduro, amante de los juegos y contestatario. Aparece en escena el eclesiástico Abad y Queipo, quien informa a Hidalgo las preocupaciones del obispo sobre la mala influencia que éste representa y su posible destitución como regente del colegio. Vigilado por la Iglesia que cuestiona su lectura de libros prohibidos, se le insta a obedecer, a lo que Hidalgo se niega.

De pronto, Hidalgo deambula por las calles oscuras y marginadas de la ciudad, por las que pululan prostitutas y borrachos, se introduce en una cantina donde le sirven pulque y se encuentra con un antiguo conocido que se dedica a la nigromancia. Con una trampa orquestada por las autoridades reales, el nigromante es apresado frente de Hidalgo, quien sólo baja la vista negando conocerlo.

En otra escena aparece en su casa en compañía de sus hijos y una mujer que pasa por su amante; como un padre amoroso ayuda a rezar a sus críos, mientras su rostro proyecta preocupación y angustia. Luego, invitado por el obispo de Michoacán, participa en una charla sobre la decapitación del rey francés, y cuando se le pregunta lo que piensa, responde que "todo pueblo tiene derecho a deshacerse de un tirano si está en riesgo el bien común". Inmediatamente se cambia la conversación y el obispo, de manera incriminatoria, pregunta por sus hijos, Hidalgo toma el asunto con naturalidad.

El obispo con postura amenazante informa a Hidalgo de su deuda con el Colegio de San Nicolás y su nuevo puesto de párroco de San Felipe, lo que parece ser un castigo por su conducta infractora. Con las miradas encima, Hidalgo se despide de sus vástagos y parte a San Felipe.

En este pueblo es recibido por el párroco Diego de Beer, quien le entrega la casa en la que vivirá y que se convertirá en un espacio de "convivencias inapropiadas". También aparece en escena el eclesiástico Francisco Ramírez, personaje que se encargará de vigilar y juzgar las acciones del cura 
Hidalgo. En San Felipe, nuestro personaje principal se transformará en protector de los indios y será acusado de convivir con las "peores heces y escorias del mundo". En su casa, que fue conocida como la "Francia chiquita", se bailaba música prohibida, se hacían fiestas escandalosas, era la guarida de sus amores prohibidos con Josefa Quintana, y en ella también se intentó representar la obra de teatro Tartufo (de Moliére), la cual quedó inconclusa, debido a la denuncia hecha por el párroco Ramírez.

Aquí se deja ver a un Hidalgo que busca la libertad de "ser él mismo". Apesadumbrado por sus deudas inventadas, perseguido por su conducta desobediente y desinteresado de las cosas materiales, mueve sus reflexiones hacia las injusticias cometidas por los gobiernos tiranos hacia el pueblo, fortaleciéndose su posición de descontento ante las desigualdades sociales. La obra del Tartufo le sirve como espejo, al asumir una postura hipócrita y de impostor ante el modelo de vida eclesiástica.

\section{3.- La dicotomía orden/transgresión.}

Tenemos muy claro que existen posturas que plantean que la historia oficial ha deshumanizado a los próceres nacionales latinoamericanos, como Bolívar, San Martín y Miguel Hidalgo, quienes fueron erigidos como "padres fundadores" perfectos y lejanos de las "pasiones humanas". Por esta razón se cree necesaria una revisión sobre los relatos históricos de los héroes nacionales, para devolverlos a su condición de hombres verdaderos. Esta postura ha sido retomada principalmente desde la literatura y el cine (Kohan, 2005, p. 1083).

En este proceso "se produce una desmitificación a todos los niveles como consecuencia de introducir dosis de realidad, parodia, ironía y cotidianidad en las nuevas obras", lo que provoca una humanización del personaje principal. Sin duda, la ironía y la parodia se convierten en el principal motor de la desmitificación de los héroes clásicos. (Pérez Parejo, 2014, pp. 85 y 90)

Y es que debemos tomar en cuenta que la construcción de un "Padre de la Patria", con una "personalidad inmaculada, es una tradición cristiana". Efectivamente, todo parece indicar que la 
modelización oficial de estas figuras heroicas se encuentra fuertemente influenciada por la hagiografía: se trata de seres extraterrenos, intachables, que nunca fueron presa de la duda ni de la vacilación, y que nacieron para ser mártires a favor de sus semejantes.

Este procedimiento semiótico moldea de manera específica la figura del héroe que se sacrifica por su patria, al igual que un santo defiende y muere por su creencia en Dios. Esta relación que se establece entre personalidades cívicas y religiosas presenta a los héroes con una imagen cercana a la santidad, ocultando sus fallas y sus errores, en otros términos, históricamente los “descircunstancializa”. (Gaspar, 2012, pp. 106 y 107)

Por eso es muy común que los textos que buscan humanizar/desmitificar a un personaje de esta naturaleza, pretendan utilizar aspectos que mellen el aura de santidad promovido por la historia oficial. Así, es común que se develen aspectos sensuales y, desde el punto de vista del oficialismo, inmorales. Surge entonces el héroe terreno, con debilidades y desaciertos. (Gaspar, 2012, pp. 13 y 104)

Dentro del texto fílmico Hidalgo. La historia jamás contada, podemos encontrar una estructura profunda en la cual se presentan dos polos opuestos. El primero está modelizado por el control de las instituciones (Estado e Iglesia), las élites y la moral; el segundo, por la libertad de pensamiento, las clases populares y la inmoralidad. De ahí que destaquen las nociones en oposición orden/transgresión. Para poder realizar el análisis, es necesario describir algunas escenas que resaltan este par dicotómico, que irá a la par de otra, constituida por los términos humanización/desmitificación, articuladas en el personaje histórico.

Desde la primera escena de la película, se observan los pilares del poder que están representados por la Iglesia y el Estado, que condenan las supuestas tropelías del personaje principal. En su celda, mientras espera ser ejecutado, Hidalgo esta postrado ante el juez inquisitorial de la Iglesia; maldecido por todas las "potestades divinas" y torturado por sus agravios en contra del Rey y de Dios, es juzgado por la muerte de españoles, robos, rapiñas, herejías, sacrilegios; asimismo es 
expulsado de la Iglesia y entregado a las autoridades reales para que sea también castigado por sus crímenes en contra del Rey. Veamos:

¡Que la santa cruz de la cual descendió Cristo triunfante sobre sus enemigos, te maldiga!

¡Que la santa y eterna madre de Dios la Virgen de Guadalupe, a la que tomaste con engaños como estandarte, te maldiga!

¡Que todos los ángeles, los principados, los arcángeles, las potestades y todos los ejércitos celestiales, te maldigan!

¡Y por todas las desgracias que le causaste al país, por la sangre derramada, por los robos, las rapiñas, por los sacrilegios que cometiste, y por las muchas afrentas contra Dios, te expulsamos del seno de la Iglesia!

(Escena 1, "Expulsión y Castigo")

En la segunda escena, el joven Hidalgo muestra interés por la lectura de libros prohibidos, los cuales consigue a través de un indígena asociado con la nigromancia. Estas acciones van en contra de las reglas impuestas por la inquisición española. Incluso, en esta misma escena, los alumnos del colegio, por medio de una representación teatral, debaten sobre la tiranía de los gobiernos y la utilización de la razón sobre la fe. Pareciera que el ambiente de libertad de pensamiento promovido por los jesuitas, como el padre Urquiza, molesta a las autoridades reales que deciden en 1767 expulsar a dicha orden religiosa del imperio español, mandando como mensaje que el deber de los súbditos es "callar y obedecer". En esta escena se destaca el siguiente diálogo del padre Urquiza, un soldado de la corona y el joven Hidalgo:

Padre Urquiza: ¡Qué pasa?

Soldado de la Corona: -Qué nos libramos para siempre de la maldad de los jesuitas-

-El Rey nuestro señor ha ordenado que salgan, ique se vayan para siempre del reino!-

Hidalgo: - ¡Padre Urquiza, porque se los llevan! ¿Qué hicieron?

Padre Urquiza: iNo sé, el Rey nos manda a callar y obedecer, esa es la explicación que nos dan! (Escena 2, "Todavía eres estudiante") 
Otro momento importante en la trama, es el debate generado por las lecturas de Hidalgo como profesor del Colegio de San Nicolás en Valladolid de Michoacán. El punto central de la discusión se remite a discernir sobre la tiranía, la libertad y la igualdad. Hidalgo se pone del lado de la libertad y critica a los gobiernos tiranos, aduce que no se puede renunciar a la libertad porque "sería como dejar de ser hombres". Un alumno le increpa que eso no es teología, mientras que el alumno Morelos apoya la postura de su maestro y agrega que la libertad se conserva aún estando presos o tiranizados".

Las discusiones que se generan en estas cátedras son conocidas por los altos jerarcas de la Iglesia, quienes vigilaban a su rebaño y tenían información de la conducta licenciosa que llevaba el rector del Colegio de San Nicolás. Para ponerle remedio a esta situación, emprenden varias acciones, entre ellas la de enviar al eclesiástico Manuel Abad y Queipo a entrevistarse con él, para instarlo a respetar las leyes de la Santa Iglesia Católica. Se le informó que el Obispo tenía la idea de que era una mala influencia y que haría todo lo posible por removerlo del cargo. En defensa, Hidalgo criticó la pompa y el boato con los que se manejaba el señor Obispo; sin embargo, le dejaron claro que sus lecturas eran peligrosas, por lo que debía de tener cuidado de las acciones que se pudieran tomar en su contra. Y así fue, el Obispo San Miguel aprovechó los deslices de la conducta de Hidalgo para destituirlo del cargo de rector, enviándolo de párroco al pueblo de San Felipe e inventándole una deuda de ocho mil pesos para tenerlo sujeto al yugo eclesiástico. Un ejemplo es la interlocución que tienen Abad y Queipo e Hidalgo:

Abad y Queipo: iSeñor Hidalgo! -El obispo piensa que usted es una mala influencia y hará todo lo posible para que deje la rectoría, pues cree que su conducta es impropia-

Hidalgo: -Más impropios es el boato, y la pompa, y los convites que organiza el señor Obispo-

Abad y Queipo: -Yo creo que usted no es quién para acusar así a un prelado-

Hidalgo: iUn prelado que nunca ha pensado en el bien de los demás, sólo en el suyo propio! 


\begin{abstract}
Abad y Queipo: -Esas son algunas de las cosas que inquietan a nuestro Obispo, lo hacen dudar de dejar en sus manos el alma de nuestros jóvenes-

Hidalgo: Mi cátedra se sustenta en los libros autorizados-

Abad y Queipo: -No es su cátedra-, jes lo que dice ex cátedra!, -En realidad yo sólo he venido a prevenirlo, pero si no quiere oír, tenga cuidado, que ya se sabe que sus lecturas son peligrosas-

(Escena 3, "La libertad es de todos")
\end{abstract}

En San Felipe, el párroco Hidalgo recibe la parroquia del padre Diego de Beer y tiene su primer encuentro con el comerciante don José Quintana, quien reconoce una obra de teatro entre los libros del ex-rector del Colegio de San Nicolás. Al compartir dicha afición, se crea una complicidad y profunda amistad entre estos dos personajes. Casi a la par de encontrar a un amigo en José Quintana, descubre husmeando entre sus libros al eclesiástico Ramírez, con quien desde el principio se generará una antipatía personal; este último actúa de manera inquisitorial, vigilante e hipócrita. El padre Ramírez se presenta como un guardián celoso de los preceptos católicos y de clase, y a través del maltrato excluye a las clases marginadas. En ese contexto, el cura Hidalgo toma la postura contraria y se convierte en protector de estos grupos, tratándolos como sus iguales.

Parece que Hidalgo se siente cómodo en los ambientes marginados y no tiene problemas en hospedar en su casa a toda su parentela y a un grupo de músicos andantes que se encargarán de alegrar sus convites. Las injusticias cometidas por los patrones en contra de los sirvientes indígenas del pueblo, entristecerán al cura, y le provocarán un sentimiento de impotencia. Estos agravios serán desahogados por estos grupos en los tiempos de la guerra de Independencia a través del robo, matanzas, y desórdenes en contra de los españoles, como lo muestran los recuerdos que tiene Hidalgo dentro de su celda.

En el corte escenográfico número ocho titulado "Yo propongo un brindis", se representa una fiesta organizada por Hidalgo en su casa, además de música prohibida, circulan bebidas embriagantes. Alejado del modelo de vida tradicional y rodeado de un ambiente bohemio, se 
convierte a los ojos de Isabel Berenguer (mujer que pregona la castidad y las buenas conductas) en una mala influencia para sus semejantes. Ella es invitada y participa momentáneamente en un baile prohibido, para inmediatamente arrepentirse y luego lanzar una serie de acusaciones contra Hidalgo y sus seguidores. A Hidalgo le dio el título de "demonio" y afirmó que sus fiestas eran una calamidad para las almas pías, asegurando también que en su casa no se respetaba ni el pudor ni la castidad y que se promovían las costumbres francesas.

En esta misma escena, don José Santos Villa, músico amigo de Hidalgo, propone un brindis y toca una canción "de mal gusto", por ser una baile de negros y porque su contenido relata la historia de un fraile de la Merced que busca los placeres de la sexualidad. Este músico además de amigo del cura, es su cómplice en este mundo bohemio. En todos estos hechos aparecerá la mirada vigilante del párroco Ramírez.

En otra escena, aparece Don José Quintana, minero y comerciante, quejándose de la ruina que están padeciendo por el pago del diezmo a la Santa Iglesia, así como los préstamos forzados que se otorgan a la corona para financiar su guerra contra los ingleses; Hidalgo se muestra en acuerdo con él, y le informa que por ese motivo las colonias inglesas se rebelaron, concluyendo los dos que quizá los novohispanos quisieran lo mismo.

Don José Quintana invita a Hidalgo a montar una obra de teatro, quien acepta gustoso y propone la caracterización de la obra del Tartufo, de Moliére. Mientras el cura se dedica a traducir esta obra francesa que está prohibida por la Iglesia, las imágenes de la trama se alternan con las acusaciones que escriben los enemigos de Hidalgo, en un documento dirigido al Obispo San Miguel sobre la conducta licenciosa del párroco de San Felipe. De él se dice que baila música prohibida, que su casa es una "Francia chiquita", que no conoce el recato ni el pudor, incluso lo llaman "jinete del apocalipsis"; la misma Isabel Berenguer asegura que Hidalgo había atentado contra su castidad; inmediatamente aparece una imagen de Hidalgo traduciendo el Tartufo, pronunciando la palabra ¡falso!, haciéndolo ver como una respuesta a estas denuncias. En este sentido, la superposición de 
imágenes ayuda a reforzar la idea de la oposición entre valores (volveremos posteriormente sobre este aspecto).

La llegada de Josefa Quintana y su estilo sensual, provoca una irrupción en las emociones de Hidalgo, quien desde ese día busca cualquier oportunidad para estar cerca de ella. A partir de ese momento, el erotismo permea la trama de la película. Veamos, el siguiente diálogo del primer encuentro entre Hidalgo y Josefa cuando son presentados por don José Quintana:

Hidalgo: -Señorita Quintana es un placer- (la mira fijamente y le besa la mano) -El diestro Marroquín, nuestro anfitrión-

Josefa Quintana: -¿Así que también le gustan los toros?- (lo mira retadoramente)

Marroquín: ¿Y a usted no?

Josefa Quintana: -No todos- iSólo los bravos! (mira a Hidalgo y luego se voltea) (Escena 11, "La llegada de Josefa")

La representación de la obra de Tartufo envolverá a los participantes en una fusión con los personajes durante el lapso que preparan el montaje; mientras esto pasa, Hidalgo continúa con su convivencia con los indígenas del pueblo, además de oficiarles misa, les enseña los trabajos de artesanías que pueden elaborar para buscar la subsistencia. Enseguida, las imágenes muestran al eclesiástico Ramírez llevando las denuncias sobre Hidalgo al prelado Abad y Queipo; con odio, relata cada una de las supuestas afrentas de aquél a la moral religiosa. Abad y Queipo, más que ponerse en alerta por estas acusaciones, se preocupa por hacerle pagar la deuda que Hidalgo tiene con el Colegio de San Nicolás, y termina nombrando como cobrador de dicho compromiso al párroco Ramírez. Estas acciones nos muestran que el alto clero representado por Abad y Queipo se interesaba más por los aspectos materiales que por los espirituales.

Una escena interesante es la que muestra a Hidalgo y Josefa Quintana en el confesionario de la iglesia, los dos personajes mantienen una complicidad tácita que los lleva a sincerar sus emociones, ella, más que confesarse, incita al cura a desnudar sus verdaderos sentimientos. Incluso salen del confesionario para seguir su conversación mirándose a los ojos; Josefa le comenta los 
deseos de su padre de verla casada, Hidalgo le responde "Es muy difícil ser lo que uno quiere ser, pero todavía es más difícil que los otros lo entiendan". Sentados en una banca de la iglesia, se confiesan el uno al otro, mientras un ambiente sensual provocado por las palabras y miradas rodea el recinto. Hidalgo aprovecha la ocasión para invitar a Josefa a participar en la obra de Moliére, a pesar de que el padre de ella estaba en desacuerdo, como lo muestra el siguiente diálogo:

Josefa Quintana: -Mi padre cree que alejándome del peligro voy a estar a salvo- (En ese momento, mientras ellos se miran fijamente, se interpone entre los dos, un candelabro con velas encendidas)

Hidalgo: -Y a usted le parezco peligroso-

Josefa Quintana: -No, ni tampoco soberbio-

(Escena 13, "Vengo a confesarme")

Josefa se convierte en la confidente de Hidalgo, a ella le manifiesta la persecución de la que es objeto por parte de la curia eclesiástica. En cada contacto crece la atracción entre los dos. Finalmente, estos deseos se consuman en una noche en que Josefa llega clandestinamente a la casa de Hidalgo. A la mañana siguiente, aparece don José Quintana, padre de Josefa. Enojado por las acciones de la pareja, da un golpe a Hidalgo.

Finalmente, el día de la presentación de la obra de Tartufo que aglomera a toda la población, don José Quintana participa con su hija, perdonando a Hidalgo por la afrenta. En esta representación de teatro, el público se envuelve con los diálogos de los actores. Este evento ha causado el malestar del párroco Ramírez, que cegado por su odio hacia Hidalgo, denuncia ante las autoridades reales la representación de la obra prohibida. Hay que recordar que en los tiempos de la colonia, la transformación del imaginario colectivo fue logrado gracias a la utilización de instrumentos como el teatro, que cumplió una función pedagógica. Por lo tanto, la obra de Tartufo se convierte en un transmisor de mensajes que cuestionan el orden establecido.

Hidalgo le revela a don José Quintana que se ha convertido en lo mismo que Tartufo, en un impostor, en un hipócrita y que desea dejar el curato para estar al lado de su hija Josefa. Sin 
embargo, la representación final de la obra queda inconclusa por la aparición de los soldados de la corona que destruyen el escenario y corren al público.

A continuación presentamos un esquema de los núcleos semióticos que aparecen en las escenas citadas.

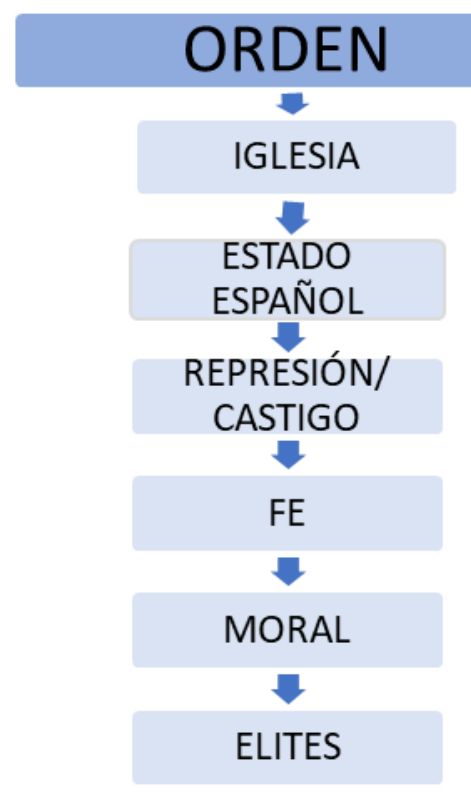

\section{TRANSGRESIÓN}

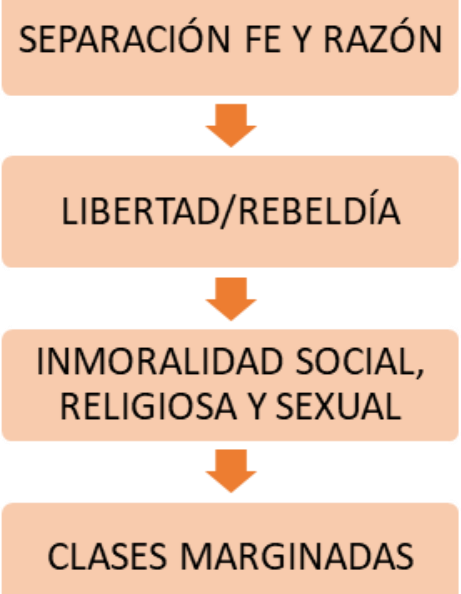

Como se ha visto, nos hemos centrado en una estrategia de lectura específica: mostramos fragmentos del texto en donde es muy evidente la aparición de diversas zonas semánticas en conflicto. En un principio, Hidalgo es juzgado por la institución eclesiástica, como un transgresor. Desde este momento, las reglas de lectura ya se empiezan a conformar: Hidalgo estará siempre modelizado por la connotación principal de trangresor. Por el otro lado, los representantes de la Iglesia son elementos metonímicos que representan a la institución eclesiástica en su totalidad. Dicha oposición se presentará incontables veces en nuestro texto, por ello es que la denominamos dicotomía hegemónica. Inmediatamente se establece la articulación castigo/rebeldía que forzosamente actualizará la referente al orden y a la transgresión. La marca semántica rebeldía acompañará toda la trama de la película. 
De acuerdo a los tiempos narrativos de la cinta, el presente se remite a Hidalgo encerrado en su celda, allí en soledad y distante de las multitudes que lo convirtieron en profeta, reconoció un dolor que no era de arrepentimiento por haber iniciado la Independencia, si no de remordimiento por la violencia desatada que no pudo prever, y que quizá no deseó.

Se verifican entonces diversas analepsis que rompen el orden cronológico, comenzando por su juventud como estudiante del Colegio jesuita de Pátzcuaro. Ahí, encontramos algunas huellas transgresoras de este personaje que, aunque forma parte de una comunidad religiosa, ejecuta sus acciones cotidianas que pueden considerarse contrarias a la moral católica: el gusto de lecturas prohibidas por la Inquisición española, el trato con un nigromante, así como la falta de vocación para ser eclesiástico. En adición, lo anterior se desarrolla dentro de un marco contextual que es la expulsión de los jesuitas, quienes representan un atentado contra el orden establecido.

Las acciones anteriores llevan implícitas dos cosas: El ejercicio mental de separación fe/razón por la influencia de sus maestros en el colegio jesuita, producto de un pensamiento ilustrado y la aparición de un incipiente sentimiento de rebeldía para acatar las normas. Claramente se comienza a manifestar la oposición hacia el orden establecido. La expulsión de los jesuitas del imperio español en 1767, marca la vida del joven Hidalgo y consolida su visión crítica hacia los gobiernos tiranos que reprimen y coartan las libertades.

En este contexto encontraremos la representación simbólica de los libros como reforzadores de la noción rebeldía y libertad de pensamiento. Este proceso de simbolización nos permite hacer visibles el opósito Fe/Razón, este último identificado con el personaje histórico de Hidalgo.

Otro ejemplo que deja ver la actitud de Hidalgo para debatir sobre asuntos considerados subversivos por el Estado español, se sitúa en su práctica como catedrático del Colegio de San Nicolás. El aula de clases en un colegio católico se convierte en el espacio en el que Hidalgo reproduce discursos contestatarios. La lectura de libros sobre historia y filosofía, le dan las herramientas para cuestionar las opresión tirana ejercida por algunos gobiernos, poniéndose del lado 
de la libertad de los hombres, como lo proponía la Revolución Francesa y la independencia de las colonias inglesas de América.

Estos discursos, promovidos por Hidalgo, serán considerados peligrosos para la armonía y tranquilidad de la corona española, que había puesto en el paquete de prohibiciones todo lo que tuviera que ver con las ideas de la llustración francesa. Hidalgo se presenta como un revolucionario del pensamiento, adelantado al tiempo que está viviendo. Es el pastor que incita a su rebaño a pensar por sí mismos y criticar todo. De ahí que la noción de la rebeldía aparezca en las ideas contestatarias promovidas por el cura. En síntesis, el espacio del colegio se presenta como un reproductor de discursos en oposición (contestatario/oficial), acorde, dicha oposición, con las dinámicas sociales del momento histórico.

El opósito élites/clases marginadas se muestran en varios momentos de la trama fílmica: las élites siempre del lado del orden, de la legitimidad eclesiástica y Estatal, de la buena moral, la justicia y la fe. Mientras que las clases marginadas son representadas en las conductas transgresoras, inmorales, irreligiosas y rebeldes. En esta posición, Hidalgo personifica el advenimiento de nuevos códigos de asimilación, interpretación y categorización de la realidad. Por lo tanto, aunque por nacimiento y por el lugar que ocupa como miembro de la comunidad eclesiástica, se resiste a compartir el sistema nocional que caracteriza a la élite novohispana y se convierte en un transmisor de códigos identificados con una ideología rebelde y contestataria que cuestiona el orden establecido y, en su rol actancial, pasa a formar parte de las clases marginadas.

La humanización/desmitificación que sufre la figura del héroe, se visibiliza en la modelización erótica, sensual, bohemia y juguetona que se presenta en el filme y que se aleja de la historia oficial. Durante toda la trama, el rol actancial de Hidalgo gira alrededor de la transgresión, la cual se manifiesta siempre como un cuestionamiento al acatamiento de normas y preceptos instituidos por un sistema de valores promovidos por la Iglesia y un conjunto de leyes dictadas por la corona española. Por lo que las tentativas de rebasar los límites impuestos, llevan a una ruptura, un 
rompimiento, una independencia, que quedan inconclusos y que remiten, por lo tanto a la marginación, la represión y el castigo.

Los núcleos semióticos presentados en el texto fílmico, asocian a Hidalgo con varias prácticas sancionadas por el sistema prohibitivo impuesto por el orden dominante: tuvo trato con mujeres, se convirtió en padre, tuvo gusto por las lecturas francesas, participó en fiestas escandalosas, promovió y desarrolló talleres artesanales, viñedos y olivares administrados por indígenas a pesar de las restricciones de la metrópoli.

Después de haber sido destituido como rector del Colegio de San Nicolás en Valladolid, Hidalgo vive una especie de exilio en el pueblo de San Felipe, y su casa se convertirá en un espacio que acoge a marginados-transgresores liderados por el cura. De hecho, la casa se encuentra en las afueras del pueblo, y había pertenecido a una familia arruinada por las políticas fiscales impuestas por la corona hacia los novohispanos; casi destruida, fue entregada a Hidalgo, quien dio hospedaje, como se dijo, a familiares y músicos andantes. Fue conocida como la "Francia Chiquita", por las tertulias que ahí se organizaban y los temas que se discutían. Más que por posición social, la marginación en este filme se moldea por funciones semióticas que evocan las nociones de inmoralidad social, religiosa, sexual y política.

Sin embargo, este grupo de marginados lidereados por Hidalgo, resemantizan el significado de ese opósito y lo asocian a nociones como la rebeldía, la libertad, el uso de la razón sobre la fe. Y conscientes de dicha tensión de ruptura y de no integración, promueven de una nueva interpretación la marca textual orden, ligada a diversas connotaciones como represión e hipocresía. Un ejemplo de ello es la canción que el músico José Santos interpreta en unos de los convites de Hidalgo:

En la esquina esta (sic.) parado

un fraile de la Merced

con los abitos (sic.) alzados

enceñando (sic.) el chuchumbé.

Que te pongas bien 
que te pongas mal

el chuchumbé te he de soplar

(Archivo General de la Nación, Inquisición, vol. 1052, exp. 20, ff. 292-299r y 302303)

La primera estrofa contiene versos compuestos por un discurso que, mediante desplazamientos semánticos contextuales, provocan un doble sentido y nos remiten al ámbito de la sexualidad. Vemos cómo se alude a un fraile que transgrede uno de los principios básicos de los votos sacerdotales, a saber, la abstinencia sexual. Además, con la mención de ese fraile genérico se define de manera lúdica el proceder del cura Hidalgo.

La función del intertexto no se limita a su sola presencia en un texto. Hay que entender al intertexto como una entidad que, puesta en una relación paradigmática con otra, se encarga de traducirla o delimitarla, de suerte que proporciona claves de interpretación sobre el texto englobante (González Vidal, 2008). Estamos hablando, pues, de que la canción abunda y refuerza lo comentado ya sobre la dicotomía principal.

En ella aparece la noción del erotismo y la transgresión sexual, la letra se refiere a los deslices de un eclesiástico, igual que Hidalgo. Hay que recordar que nuestro personaje principal es humanizado en el filme a través de la modelización erótica. Se presentan entonces las emociones amorosas del cura, que al mismo tiempo son un indicio de la cultura hipócrita que permeaba a la sociedad colonial de la Nueva España.

Esto se nota más claro en la descripción una escena anteriormente aludida. Nos referimos al momento en el que Hidalgo se encuentra en el confesionario con Josefa Quintana. La confesión religiosa se deconstruye y desemboca en otro tipo confesión, matizada por el erotismo y por la atracción mutua. Hidalgo se postra frente a Josefa, quien lo mira con aire sensual; al fondo, entre los dos se aprecia un candelabro, cuyas velas están encendidas. En este preciso momento, el candelabro sufre una resemantización: la noción religiosa del instrumento queda disminuida por la relación erótica que se establece por la pareja; de esta forma pasa a ser un instrumento de unión amorosa. 
Las velas encendidas representan la pasión, lo que constituye una connotación altamente convencionalizada del fuego.

Por lo anterior, pudimos observar la dicotomía orden/transgresión como una dialéctica regida no sólo por los roles actanciales de los personajes, sino también por los espacios y objetos que forman parte de esta unidad semántica. Las transgresiones comprenden las dimensiones de lo social, lo religioso y lo político de acuerdo a la estructura del poder dominante y, por este motivo y por las connotaciones que implican (rebeldía/libertad), son necesaria e ineludiblemente punibles.

El título mismo, Hidalgo. La historia jamás contada, en fu función de paratexto, despierta la expectativa de que los recorridos de lectura del filme se apartarán de la versión oficialista de este episodio histórico, hecho que se confirma por una articulación nocional cuyo eje fundamental se estructura con base en la transgresión.

\section{5.- Conclusiones}

Tradicionalmente hemos ubicado a Hidalgo como un ícono de las narrativas dominantes que han sido generadas por el Estado mexicano, ícono que en un proceso de expansión prácticamente ininterrumpido ha pasado a formar parte de producciones del arte popular y del elitista, de la socialización escolar, de las conmemoraciones anuales y de otras formas de inmortalización cultural. Esto lo plasma como un factor de vital importancia en la construcción de una identidad nacional.

Es verdad que el cine es concebido primordialmente como en fenómeno de entretenimiento, pero como hemos visto a lo largo de este trabajo, tiene otras funciones. La película de Serrano tiende a una desmitificación del llamado "Padre de la Patria", y como consecuencia promueve -de manera consciente, no consciente o inconscientemente- la idea de una revisión histórica.

Ahora bien, el texto analizado se caracteriza por dos aspectos contradictorios entre sí. En primer lugar, esta deconstrucción de la visión oficial de la historia nacional. En este sentido, se nos muestran hechos de la vida de Miguel Hidalgo que fueron omitidos en gran parte por el discurso 
oficial dominante, lo cual lo convierte en un ser más cotidiano, cercano a la vida común, en pocas palabras, más humano.

Sin embargo, también se presenta la visión comercial. Los hechos que permanecían ocultos sobre la biografía de este cura, provocan morbo y tienen, de acuerdo con Jakobson, una función conminativa. El cartel promocional en que aparecen los personajes de Josefa Quintana y de Miguel Hidalgo, apunta a una relación erótica, cuyo interés es llamar al público a consumir el producto cinematográfico y, de esta forma, producir ganancias económicas.

Una de las ventajas de esta clase de análisis, es la posibilidad de localizar las contradicciones que, de acuerdo a las circunstancias socio-históricas de emergencia, se introducen en un producto cultural.

\section{Referencias:}

Archivo General de la Nación, Inquisición, vol. 1052, exp. 20, ff. 292-299r y 302-303.

Certeau, M. (1993) La escritura de la historia. México: Universidad Iberoamericana.

Chartier, R. (2005) El presente del pasado. Escritura de la historia, historia de lo escrito. México: Universidad Iberoamericana.

González, J-C. (2008) Semiótica y cine: lecturas críticas. México: Universidad Michoacana de San Nicolás de Hidalgo.

Kohan, M. (2005) “La humanización de San Martín”. En Revista Iberoamericana. (213), 1083-1096.

Lara C, (28 de enero de 2018). "La historia también es pura ficción": Antonio Serrano. Correcamara. Recuperado de: http://www.correcamara.com.mx/inicio/int.php?mod=noticias detalle\&id noticia=2089

Margarito, M. (2012). "La desmitificación del héroe histórico en la obra de Ibargüengoitia". En Études romanes de Brno. (33). 97-109. 
Molina, T. (30 de enero de 2018). “Recrea cinta a un cura pícaro, que se amargó con el tiempo" La Jornda. Recuperado de: http://www.jornada.unam.mx/2010/09/11/espectaculos/a07n1esp

Pérez, R. (2014) "La desmitificación del héroe en el paso de la épica a la novela española. Teoría y textos". En Nueva Revista del Pacífico. (61) 87-99.

Serrano, A. (Dir.) (2010), Hidalgo la historia jamás contada, cinta cinematográfica, México, Imcine20th Century Fox. 